\title{
Relation between diet and protozoal population in the rumen
}

\author{
By M. ABE, H. SHIBUI, T. IRIKI AND F. KUMENO \\ Laboratory of Nippon Formula Feed Manufacturing Co., \\ 640 Higashiterao machi, Tsurumi-ku, Yokohama, Japan \\ (Received 4 February $1972-$ Accepted 7 September 1972)
}

\footnotetext{
I. Four feeding trials were made to investigate relations between diet and protozoal population in the rumen.

2. When a ration containing no concentrate was used, the number of entodiniomorphs decreased rapidly. The number of entodiniomorphs increased with the amount of concentrate. Rice straw, which was used as a sole source of roughage, was not always necessary for protozoa to survive in the rumen.

3. The type of diet affected the holotrich population to a much smaller extent than the entodiniomorph population.
}

During the past two decades there has been a gradual accumulation of information about the factors that influence the number of protozoa in the rumen (Warner, 1965 ; Hungate, I966; Eadie \& Mann, r970). For example, the physical form of ration and the frequency of feeding have generally been accepted to influence protozoal concentrations in the rumen. However, much more detailed work will be needed.

The present work describes four experiments designed to investigate the influence of the type and amount of diet on protozoal concentrations in the rumen.

\section{EXPERIMENTAL}

\section{Feeding trials}

Three Holstein cows with permanent rumen fistulas, and weighing approximately $500 \mathrm{~kg}$ each, were used in four experiments. Before each experiment, they were given a basal ration (B) and then other rations ( $I-6)$ as shown in Table 1 . They were fed twice daily at 08.00 and $\mathrm{r} 6.00$ hours and allowed free access to water.

Expt I. Effects of three rations on protozoal population in the rumen were examined. Three cows were used in a $3 \times 3$ Latin square design as shown in Table $\mathrm{r}$. The three treatment periods were $5 \mathrm{~d}$ each. As ration 2 contained no roughage and was generally poor, each treatment period was followed by Io d intervals on ration $B$ to restore the condition and appetite of the animals. On the last days of three treatment periods, samples of rumen fluid were collected at 15.30 hours through the fistula by the use of a vacuum pump and a rubber tube.

Expt 2. Three cows were used in a $3 \times 3$ Latin square design as given in Table $I$. No recovery intervals were allowed between treatment periods of $7 \mathrm{~d}$. Rumen fluid samples were collected from each cow at I 5.30 hours on the last days of three treatment periods.

Expt 3. Two cows were used in a $2 \times 2$ Latin square. Two experimental rations 
Table I. Feeding regimens of cows in four trials

\begin{tabular}{|c|c|c|c|c|c|}
\hline \multirow[b]{2}{*}{ Expt no. } & \multirow[b]{2}{*}{ Ration } & \multirow[b]{2}{*}{ Cows } & \multicolumn{3}{|c|}{ Composition of daily ration $(\mathrm{kg})$} \\
\hline & & & $\begin{array}{l}\text { Chopped } \\
\text { rice straw }\end{array}$ & $\begin{array}{l}\text { Lucerne-meal } \\
\text { pellet }\end{array}$ & $\begin{array}{l}\text { Concentrate } \\
\text { mixture* }\end{array}$ \\
\hline $\mathbf{I}$ & $\left.\begin{array}{c}\mathrm{B}^{\dagger} \\
\mathrm{I} \\
2\end{array}\right\}$ & 3 & $\begin{array}{l}3 \\
3 \\
\end{array}$ & $\begin{array}{l}3 \\
3 \\
3\end{array}$ & $\frac{\text { I.5 }}{-}$ \\
\hline 2 & $\left.\begin{array}{l}\mathrm{B} \dagger \\
3 \\
4\end{array}\right\}$ & 3 & $\begin{array}{l}3 \\
3 \\
3\end{array}$ & $\begin{array}{l}3 \\
3 \\
3\end{array}$ & $\begin{array}{l}\mathrm{I} \cdot 5 \\
5 \\
0 \cdot 5\end{array}$ \\
\hline 3 & $\left.\begin{array}{l}5 \\
6\end{array}\right\}$ & 2 & $\frac{4}{-}$ & $\begin{array}{l}\mathrm{I} \\
\mathrm{I}\end{array}$ & $\begin{array}{l}3 \\
3\end{array}$ \\
\hline 4 & $\left.\begin{array}{l}6 \\
7\end{array}\right\}$ & 2 & - & $\begin{array}{l}\text { I } \\
\text { I }\end{array}$ & $\begin{array}{r}3 \\
12\end{array}$ \\
\hline
\end{tabular}

* Concentrate mixture composed of $(\mathrm{g} / \mathrm{kg}): 372$ cereal grain, 288 bran, 274 plant-oil meal, 40 molasses and 26 minerals.

+ Basal.

were used in this experiment. The treatment periods followed rod intervals for the same reason as in Expt I when, during the intervals, ration B was given to the cows. Rumen fluid samples were collected at 15.30 hours on the 5 th day of each treatment period.

Expt 4. Two cows were used in a $7 \mathrm{~d}$ feeding trial (see Table I). Before the trial each cow was given ration B. Rumen fluid samples were collected at 15.30 hours immediately before the ration was changed and on days $x, 3$ and 7 after the change.

\section{Analytical methods}

The $\mathrm{pH}$ and redox potential were measured immediately after the collection of samples. After the filtration of the remainder of the sample through two layers of gauze, protozoa were counted and chemical determinations were made.

Counting of protozoa. One volume of the prepared samples was added to two volumes of $10 \%$ formaldehyde solution containing $300 \mathrm{ml}$ glycerol and $300 \mathrm{mg}$ methyl green per 1 solution, and the mixture was stored at room temperature. The sample was further diluted with glycerol solution $(300 \mathrm{ml} / \mathrm{l})$ so that about 200 protozoa would be present in a counting cell $(\mathrm{r} O \times 10 \times 0.4 \mathrm{~mm})$. The protozoa were counted in a microscope at a magnification of $\times 100$.

Chemical determinations. The $\mathrm{pH}$ and reduction-oxidation potential were measured with a $\mathrm{pH}$ meter using a glass or platinum electrode. Ammonia content was determined by the method of Van Slyke \& Cullen (I9I4) modified by Hawk, Oser \& Summerson (1954), and total volatile fatty acids (VFA) were estimated by the method reported by Kumeno (I962).

The results were subjected to analysis of variance, and the significance of the difference between means was determined by the multiple range test (Duncan, 1955). 


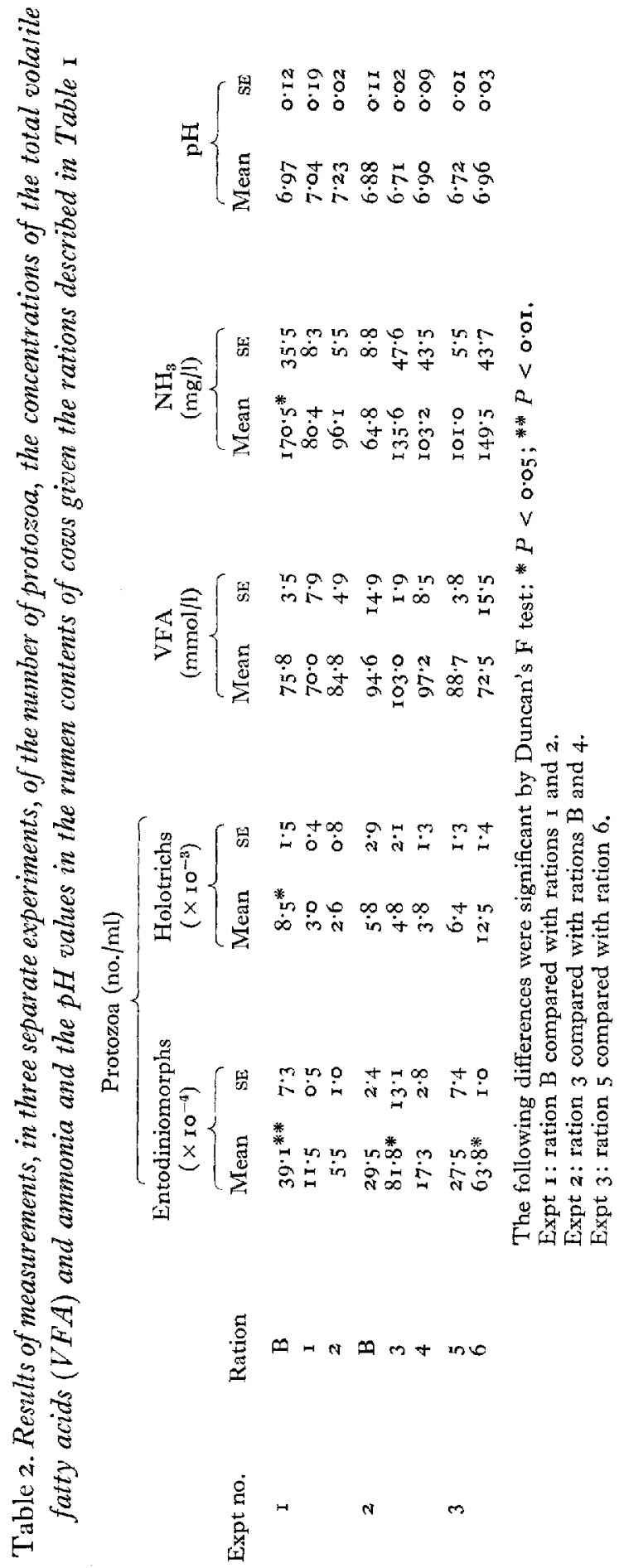


Table 3. Changes in the number of protozoa, the concentration of total volatile fatty acids $(V F A)$ and ammonia, and in the $p H$ and redox values in the rumen of cows, after the change from the basal vation $(B)$ to experimental rations 6 and 7 (for composition, see Table $\mathbf{1}$ )

\begin{tabular}{|c|c|c|c|c|c|c|c|c|}
\hline \multirow[b]{2}{*}{ Cow } & \multirow[b]{2}{*}{ Day } & \multirow[b]{2}{*}{ Ration } & \multicolumn{2}{|c|}{ No. of protozoa (no./ml) } & \multirow[b]{2}{*}{$\begin{array}{c}\mathrm{VFA} \\
(\mathrm{mmol} / \mathrm{l})\end{array}$} & \multirow[b]{2}{*}{$\begin{array}{c}\mathrm{NH}_{3} \\
(\mathrm{mg} / \mathrm{l})\end{array}$} & \multirow[b]{2}{*}{$\mathrm{pH}$} & \multirow{2}{*}{$\begin{array}{l}\text { Redox } \\
\text { potential } \\
(\mathrm{mV})\end{array}$} \\
\hline & & & $\begin{array}{l}\text { Entodiniomorphs } \\
\left(\times 10^{-4}\right)\end{array}$ & $\begin{array}{c}\text { Holotrichs } \\
\left(\times 10^{-3}\right)\end{array}$ & & & & \\
\hline \multirow[t]{4}{*}{ I } & $\circ$ & B & $43 \cdot I$ & $17 \cdot 0$ & I03.5 & $85 \cdot 8$ & 7.01 & -189 \\
\hline & I & 6 & $62 \cdot 3$ & $10 \%$ & 118.6 & $171 \cdot 7$ & $7 \cdot 11$ & -161 \\
\hline & 3 & 6 & $84 \cdot 2$ & 14.8 & 83.4 & $208 \cdot 7$ & $7 \cdot 12$ & -167 \\
\hline & 7 & 6 & $129 \cdot 3$ & 29.4 & $I I I \cdot I$ & $267 \cdot 2$ & 6.80 & -134 \\
\hline \multirow[t]{4}{*}{2} & $\circ$ & $\mathbf{B}$ & $24 \cdot 3$ & $10 \cdot 2$ & 114.5 & $121 \cdot 4$ & $7 \cdot 21$ & $-\mathrm{I} 88$ \\
\hline & $\mathrm{I}$ & 7 & 28.8 & $8 \cdot 8$ & 170.1 & $373^{\circ} 0$ & 6.22 & -127 \\
\hline & 3 & 7 & $20 \cdot 6$ & $6 \cdot 9$ & $145 \cdot 6$ & $251 \cdot 6$ & 6.10 & -87 \\
\hline & 7 & 7 & 0.2 & 0.2 & $12 \% 2$ & $\mathrm{~T} 45 \cdot \mathrm{I}$ & 5.47 & -59 \\
\hline
\end{tabular}

RESULTS

Most of the results of the separate Expts I, 2 and 3 are summarized in Table 2. The measurements of the redox potential did not vary significantly from the general mean value of $-17 \mathrm{r} \mathrm{mV}$ (range -59 to -189 ) (see Table 3 ).

It can be seen in Table 2 that, in Expt $\mathrm{I}$, ammonia concentration, and numbers of entodiniomorphs and holotrichs in the rumen, were greater in cows given the ration containing concentrate; no difference was observed in $\mathrm{pH}$ or VFA content with the three types of ration.

In Expt 2, in which different levels of concentrate were given to the cows, numbers of entodiniomorphs increased in proportion to the concentrate fraction (Table 2). No definite tendency was found in the numbers of holotrichs, $\mathrm{pH}$ or ammonia and VFA concentrations.

Table 2 also shows the effects of feeding concentrate with, or without, rice straw and some lucerne-meal pellet. On day 5, after feeding with rice straw was discontinued, a marked increase in the number of entodiniomorphs and a slight increase in that of holotrichs were observed; no significant differences were detected in rumen $\mathrm{pH}$, or ammonia and VFA concentrations.

In Expt 4, when $3 \mathrm{~kg}$ concentrate and I $\mathrm{kg}$ lucerne-meal pellet were given daily to a cow in place of ration B, composed of $3 \mathrm{~kg}$ chopped rice straw, $3 \mathrm{~kg}$ lucerne-meal pellet and $\mathrm{r} \cdot 5 \mathrm{~kg}$ concentrate (Table $\mathrm{r}$ ), a threefold increase in the number of entodiniomorphs and a slight increase in that of holotrichs were observed $7 \mathrm{~d}$ after the change in ration (Table 3). However, when $12 \mathrm{~kg}$ concentrate and $\mathrm{I} \mathrm{kg}$ lucernemeal pellet were given daily without rice straw, a marked fall in rumen $\mathrm{pH}$ and, at the same time, a marked decrease in protozoal population occurred within the same feeding period. There were also some changes in the redox potential. 


\section{DISCUSBION}

All the entodiniomorphs, except some small species of Entodinium, utilize starch, whereas holotrichs assimilate soluble sugars (Hungate, I 966). Entodiniomorphs are usually abundant in the rumen of animals given a high-concentrate ration, and holotrichs appear in the greatest numbers in animals given hay or forages rich in soluble sugars (Warner, I965). The present results are in agreement with the above findings. The numbers of entodiniomorphs increased in proportion to the amount of concentrate in the ration, and were independent of the amount of lucerne meal or rice straw. The holotrich population was affected by the rations used to a smaller extent than the entodiniomorph population. This was probably because the concentrate mixture contained little readily fermentable sugar.

Protozoa remained in the rumen even when the ration did not contain rice straw. When a limited amount of concentrate was included in the ration without rice straw, $\mathrm{pH}$ was maintained at almost the original level and entodiniomorph concentrations increased markedly. Although this increase can be partly attributed to a possible decrease of the rumen volume, the results were unexpected because such types of ration are known to reduce $\mathrm{pH}$ and protozoal population in the rumen (Purser \& Moir, 1959; Christiansen, Woods \& Burroughs, 1964). A marked decrease in protozoal population, together with the depression in $\mathrm{pH}$ below 5.5 , was found when $12 \mathrm{~kg}$ concentrate was given daily without rice straw.

The concentration of total VFA in the rumen was not affected by the amount of concentrate or rice straw given to the animals. It secms surprising that no marked change was observed in rumen VFA concentration even when $\mathrm{pH}$ dropped below 5.5 by the daily feeding of $\mathrm{I} 2 \mathrm{~kg}$ concentrate and $\mathrm{I} \mathrm{kg}$ lucerne meal without rice straw. This suggests that the marked fall of $\mathrm{pH}$ found with one cow in Expt 4 is indeed associated with the increased amount of concentrate, but can not be attributed to the accumulation of VFA. Further, it is unlikely that this depression in $\mathrm{pH}$ can be attributed to the decrease in salivary inflow, because the depression in the rumen $\mathrm{pH}$ was not observed when the daily ration was further limited to $3 \mathrm{~kg}$ concentrate and I $\mathrm{kg}$ lucerne meal without rice straw.

The present results indicate that the type and amount of diet are factors which influence the protozoal population. However, more work needs to be done to know about the complex relationship between the diet and microbial population in the rumen.

The authors thank Dr M. Kandatsu, Emeritus Professor of The University of Tokyo, for encouragement with this work.

\section{REFERENCES}

Christiansen, W. C., Woods, W. \& Burroughs, W. (I g64). F. Anim. Sci. 23, 984 . Duncan, D. B. (I955). Biometrics rI, I.

Eadie, J. M. \& Mann, S. O. (r97o). In Physiology of Digestion and Metabolism in The Ruminant p. 335 [A. T. Phillipson, editor]. Newcastle upon Tyne: Oriel Press Ltd.

Hawk, P. B., Oser, B. L. \& Summerson, W. H. (1954). Practical Physiological Chemistry 13 th ed. New York: McGraw-Hill Book Co. 
Hungate, R. E. (tg66). The Rumen and Its Microbes. New York and London: Academic Press Inc. Kumeno, F. (1962). F. agric. Chem. Soc. Fap. 36, I 8 I.

Purser, D. B. \& Moir, R. J. (1959). Aust. F. asric. Res. 10, 555.

Van Slyke, D. D. \& Cullen, G. E. (1914). F. biol. Chem. I9, 2 I I.

Warner, A. C. I. (1965). In Physiology of Digestion in The Ruminant p. 346 [R. W. Dougherty, editor]. Washington, DC: Butterworths. 